\title{
FAMILIA ÎN POSTMODERNIATE. IMPLICATุII MORALE ŞI MISIONARE
}

Gavril Trifa*

\begin{abstract}
To understand and to assume post-modernity represents one of the most topical and most sensitive issues for the Christian morals and mission in general, and for the Orthodox faith in particular. Denying all forms of authority under the pressure of liberal models, doubled by an increasingly visible presence of concepts derived from the evolutionist theory, existentialism or hedonism, bring the individual as well as the Church face to face with some challenges regarding moral and missionary models, which are the most appropriate for retaining and conveying the truths revealed by God. More and more voices show the way in which post-modernism falsifies man's true identity and redirects one's personal existence towards a way of life devoid of meaning and communion. In this context, the family is faced with the difficult task of retaining its mission of a "small-scale Church", with a direct reference to one's moral-religious development in and for communion.
\end{abstract}

Keywords: the traditional Christian family, visions of the Family, state, the contemporary secular culture.

Perioada contemporană este definită, printre alte aspecte legate de viața religioasă, de promovarea cu insistență a unor modele morale opuse tradiției creştine, contrare învăţăturii de credinţă, în general, şi a spiritualităţii creştin-ortodoxe în special. Prin glasul diferitelor concepte evoluţioniste, existenţialiste, hedoniste şi a libertinajului, societatea actuală încearcă cu orice preț să convingă omul să renunţe la demnitatea şi veşnicia pe care i le oferă şi mijloceşte Biserica, singura păstrătoare şi propovăduitoare a adevărurilor revelate de Dumnezeu. Prin retezarea rădăcinilor

${ }^{*}$ Reader PhD, West University of Timişoara, Romania. 
originii sale şi prin stoparea sau uneori chiar efortul de anulare a năzuințelor de bine şi de frumos, postmodernismul, a fragmentat, a furat omului adevărata identitate şi 1-a expulzat înspre o lume din care lipseşte tot mai mult Viața ${ }^{1}$. Naturalismul şi umanismul Renaşterii deschid lupta de dezumanizare a persoanei. Omul încearcă din răsputeri să-1 înlocuiască pe Dumnezeu fără să realizeze că prin această acțiune el se îndepărtează de bună voie de Cel care îi aduce şansa de a-şi descoperi propria identitate. „Postmodernismul apare ca o urmare, respectiv ca o continuare a modernismului, dar şi ca o realitate ce se opune modernismului prin unele aspecte proprii; deci continuare a modernismului, dar şi o reacție deconstructivistă la adresa modernismului." 2

Instituția familiei nu mai este văzută în toată sfințenia şi responsabilitatea ei, ci foarte multe cupluri ( căsătorite civil sau chiar religios) duc o viață de libertinaj moral, astfel că ,mariajul se impune tot mai mult doar ca o afacere liberă de orice reguli sau răspunderi morale, semănând mai degrabă cu o formă de concubinaj, care nu-şi propune să dureze şi să rodească, ci doar să coloreze hedonic un interval aleatoriu. Partenerul nu-i decât o prezență conjuncturală, oricând substituibilă în funcție de umori şi suportabilă numai în virtutea concesivității reciproce. $\mathrm{Nu}$ o dată se întâmplă ca partenerii să fie interşantajabili între cupluri de «prieteni»...sau ca fiecare să antameze aventuri cu buna ştiință a celuilalt, ba uneori chiar în complicitatea acestuia." ${ }^{3}$ In astfel de relații extraconjugale se foloseşte pe scară largă contracepția iar dacă apar eventuale sarcini nedorite se recurge la avort fără prea multe „scrupule inutile”.

${ }^{1}$ John M. Hull, Practical theology and religious education in a pluralist Europe, în „British Journal of Religious Education”, 2004, 26(1), pp. 7-19.

${ }^{2}$ Dumitru Radu, Postmodernismul, o provocare nihilistă la învățătura de credință şi spiritualitate ortodoxă, art. în „Simpozionul Modernism, Postmodernism şi Religie", Constanța, mai, 2005, Iaşi, Editura Vasiliana98, 2005, p. 378.

3 Răzvan Codrescu, Teologia sexelor şi Taina Nunții, Bucureşti, Edit. Christiana, 2002, nota 3, p. 19. 
Instituţia familiei, în constituţia ei originară lăsată şi binecuvântată de Dumnezeu, începe să fie astăzi tot mai contestată, dovadă fiind numărul crescut de divorțuri şi de infidelități între membrii acesteia. „Frecvența şi facilitatea destrămării căsătoriei numărul tot mai mare al divorţurilor, cu precădere în societăţile «dezvoltate» - s-ar putea să fie un simptom semnificativ al amplorii luate de contestarea practică a instituției. Însă, independent de mărturiile statistice, este clar că modul de viaţă impus nouă în cadrul civilizaţiei tehnologice autonome şi al societăţii de consum subminează (de nu cumva o exclude radical) instituția căsătoriei. Iar aceasta fiindcă, oricum, respectivul mod de viață este individualist ${ }^{4}$ : el pare a nimici posibilitătile de depăşire şi de relație personală. În cadrul lui, relația e o formă de supunere: supui ori eşti supus. De aceea refuzul fidelității față de legătura conjugală este prezentat pretutindeni ca o necesitate naturală de libertate, ca o eliberare de supunerea la convenții şi rutină, ca o deschidere către viață, care e o aventură nesfârşită de depăşire a formelor."5

\section{Familia creştină-icoană a iubirii dintre Hristos şi Biserică}

Familia creştină, întemeiată prin binecuvântarea lui Dumnezeu, este o icoană a relaţiei de comuniune dintre Mântuitorul Hristos şi Biserica Sa. Prin glasul Sf. Ap. Pavel, comuniunea familială este oglindită ca o ,taină mare”, tocmai pentru faptul că închipuie comuniunea dintre Hristos şi Biserică. Relaţia de iubire şi de supunere dintre soți trebuie să aibă ca model iubirea jertfelnică a lui Hristos pentru Biserică, dar şi supunerea Bisericii faţă de E1. În cadrul familiei, bărbatul şi femeia sunt chemaţi să se angajeze moral pe drumul ascendent al sfințeniei, după cum şi Mântuitorul a curăţit şi a sfinţit Biserica Sa şi, de asemenea, aşa precum El, „lăsând” pe

${ }^{4}$ Emma Nicholls, Arthur A. Stukas, Narcissism and the Self-Evaluation Maintenance Model: Effects of Social Comparison Threats on Relationship Closeness, în „The Journal of Social Psychology”, 2011, 151(2), 201-212.

${ }^{5}$ Christos Yannaras, Libertatea moralei, Bucureşti, Edit. Anastasia, 2002, pp. 176-177. 
Tatăl, S-a coborât pe pământ pentru Biserica cea dintre neamuri, tot astfel şi bărbatul îşi părăseşte casa părintească spre a se însoți cu femeia sa. Prezența Mântuitorului Hristos la nunta din Cana Galileii, unde a săvârşit prima minune, are o profundă semnificație teologică, evidențiată clar în slujba ortodoxă a Tainei Cununiei: „Care pentru negrăitul Tău dar şi pentru multa bunătate, ai venit în Cana Galileii şi nunta care era acolo ai binecuvântat-o, ca să arăţi că din voia Ta se face însoțirea cea după lege şi naşterea de prunci dintr-însa" (din prima rugăciunea de după ectenia mare din Slujba Cununiei). ${ }^{6}$

Principiul pe care Sfinții Apostoli îl aşează la baza unirii dintre soți este acelaşi care stă şi la baza unirii dintre Hristos şi Biserică: IUBIREA. „Bărbaților, iubiți pe femeile voastre, după cum şi Hristos a iubit Biserica, şi S-a dat pe Sine pentru ea" (Ef. 25). După cum Hristos, în marea Sa iubire pentru Biserică S-a dăruit jertfelnic acesteia, la fel iubirea dintre soți cere dăruire jertfeinică şi totală unul altuia. Sfântul Pavel consideră iubirea dintre soți ca o datorie reciprocă: „Aşadar, bărbații sunt datori să-şi iubească femeile, ca pe însăşi trupurile lor” (Ef. 5, 28) şi „Bărbatul să-i dea femeii iubirea datorată, asemenea şi femeia bărbatului" (I Cor. 7, 3).

Clement Alexandrinul se întrebă de unde-şi primeşte căsătoria sfințenia. „Căsătoria este sfântă dacă este împlinită aşa cum spune Cuvântul, dacă soțul şi soția se supun lui Dumnezeu şi dacă îşi chivernisesc viața conjugală «cu inima curată întru adeverirea credinței, curățindu-şi inimile de orice gând rău, spălând trupul cu apă curată şi ținând mărturisirea nădejdii, pentru că este credincios Cel ce a făgăduit» (Ev. 10, 22-23). O căsătorie fericită nu trebuie judecată nici după bogăție, nici după frumusețe, ci după virtute", 7 Botezul şi Pocăința, care o preced, împreună cu Euharistia - în care se săvârşeşte Taina Nunţii - răscumpără şi sfințesc Căsătoria.

Sfântul Ioan Gură de aur afirmă originea divină a legăturii dintre bărbat şi femeie, precum şi răsplata divină a celor ce respectă

\footnotetext{
${ }^{6}$ Vasile Mihoc, Căsătoria şi familia în lumina Sfintei Scripturi, în „Mitropolia Ardealului", nr. 9-10, 1985, p. 584.

${ }^{7}$ Clement Alexandrinul, Stromatele, trad. rom. D. Fecioru, în PSB, vol. 5, Bucureşti, Editura Institutului Biblic, 1982, p. 290.
} 
jurămintele făcute: „Când se vorbeşte de legăturile căsătoriei, în mod sigur se vorbeşte de un lucru sfânt şi binecuvântat de Dumnezeu. Căsătoria este o Taină mare, originea ei este divină, misiunea ei este sublimă, faptele ei sunt mari şi roditoare". ${ }^{8}$

Dumnezeu ridică legătura soților la rang de Taină dacă unirea lor se face întru Hristos şi Biserică: „Este o taină mare, zice apostolul. Da, cu adevărat destul de mare şi destul de străină! Două ființe nu se cunosc, poate nu s-au văzut niciodată. Însă Dumnezeu le rânduieşte pe unul altuia; intervine adesea o împrejurare care le apropie şi la o primă privire reciprocă se aprinde flacăra tainică a iubirii. Şi părinții? La ei de asemenea să admirăm o taină. Această fiică pe care grijile lor generoase au cuprins-o atâta vreme, de care le era insuportabil să se despartă un moment, ei o dau, ei se despart de ea, ei o înzestrează cu această zestre, ei care sunt de altfel atât de avari. Şi toată această purtare împotriva naturii se începe şi se sfințeşte cu cele mai uimitoare uşurințe. Dumnezeu este acolo. Puterea Lui şi înţelepciunea Lui poruncesc şi natura se desjudecă pentru a asculta de El. Şi să n-o pierdem niciodată din vedere. Dumnezeu schițează astfel în căsătorie taina prin excelență, unirea Cuvântului Său cu natura omenească: Taina aceasta mare este, iar eu zic în Hristos şi în Biserică".

\section{Familia creştină-implicații morale şi misionare}

În fața modelului oferit de Mântuitorul Iisus Hristos, Care a ridicat familia la rang de Taină, provocările postmodernității obligă Biserica la analize temeinice şi la elaborarea unui model misionar care să includă mai eficient căile de cunoaştere şi actualizare a cuvântului revelat, în raport cu vârsta spirituală a creştinilor de azi ${ }^{10}$. Un alt aspect pedagogic esențial este rugăciunea comună şi

${ }^{8}$ Sfântul Ioan Gură de Aur, Bogățiile oratorice, Oradea, Editura Pelerinul Român, 2002, p. 227.

${ }^{9}$ Ibidem, pp. 248-249.

${ }^{10}$ Dorin Opriş, Dimensiuni creştine ale pedagogiei moderne, Bucureşti, Editura Didactică şi Pedagogică, 2012, pp. 101-103. 
particulară făcută în cadrul familiei, reprezintă unul dintre mijloacele cele mai importante pentru menținerea şi dezvoltarea religiozităţii membrilor ei. Prin rugăciune omul vorbește cu Dumnezeu, Îl preamăreşte, Îi cere ajutorul şi-I mulțumeşte pentru binefacerile pe care le-a revărsat asupra lui. Aceasta trebuie făcută ,în duh şi în adevăr", adică din tot sufletul şi mărturisind credința cea adevărată, pentru că „Duh este Dumnezeu şi cei ce I se închină trebuie să I se închine în duh şi în adevăr” (Ioan 4, 24).

Mântuitorul Iisus Hristos ne dă ca exemplu de rugăciune curată pe cea a vameşului, care „cu inima înfrântă şi smerită”, stând în partea din spate a templului, îşi bătea pieptul şi zicea „Dumnezeule, fii milostiv mie, păcătosului" (Luca 18,13). Cu alte cuvinte, pentru ca rugăciunea membrilor familiei să se poată înălța spre Dumnezeu ea trebuie să fie nu doar comună, ci şi susținută de smerenie, prin care propriile limite devin din pietre de poticnire trepte spre cer şi împiedică declinul spiritual ${ }^{11}$, „fiindcă oricine se înalță pe sine se va smeri, iar cel ce se smereşte pe sine se va înălța" (Luca 18, 14). Dacă rugăciunea este atât de necesară pentru transformarea lăuntrică a omului, cu atât mai mult familia, în integralitatea ei, are nevoie de acest mijloc de înălțare către Dumnezeu Care face să se pogoare asupra ei harul cel de sus. Dumnezeu binecuvântează căsnicia şi face să înflorească în mijlocul ei darurile cele duhovniceşti. Hristos Însuşi a promis că „unde sunt doi sau trei, adunați în numele Meu, acolo sunt şi Eu în mijlocul lor" (Matei 19, 20), arătând prin aceasta că El este prezent într-un mod mai deosebit lângă aceia care Îi împlinesc voia şi lucrează pentru numele Lui.

În Vechiul Testament exemplu cel mai elocvent de credință şi rugăciune familială îl avem în Cartea Tobit, în care se descrie relația ce-i caracteriza pe cei doi soți, Tobie şi Sara. Aceştia obişnuiau să se roage împreună, iar relația lor se caracteriza printr-o curăție sufletească pilduitoare: „Iar când au rămas numai amândoi în cameră, Tobie s-a sculat din pat şi a zis: «Scoală, soro, să ne rugăm

${ }^{11}$ E.H. Ecklund, K.S. Lee, Atheists and Agnostics Negotiate Religion and Family, Journal for the Scientific Study of Religion, 2011. 
ca să ne miluiască Domnul!» Şi a început Tobie a zice: «Binecuvântat eşti Tu, Dumnezeul părinţilor noştri, şi binecuvântat este numele Tău cel sfânt şi slăvit în toți vecii!...Şi acum, Doamne, nu plăcerea o caut, luând pe sora mea, ci o fac cu inimă curată. Binevoieşte deci a avea milă de ea şi de mine şi a ne duce împreună până la bătrânețe! » Şi a zis şi ea cu el: «Amin!»” (Tobit 8, 4-5, 7-8). Astfel, prin rugăciune şi viaţă curată, binecuvântată de Dumnezeu, cei doi au izgonit pe demonul care încerca să-i dezbine.

Descreştinarea masivă, asupra căreia insistă lucrările de teologie $^{12}$ poate să cunoască o contrapondere semnificativă prin reaşezarea familiei pe locul pe care 1-a avut în spaţiul eclesial până în secolul XX. Sfântul Apostol Pavel arată valoarea familiei ca icoană a unităţii dintre Hristos şi Biserică, Mireasa Sa. Aşa cum Hristos este cap Bisericii universale, la fel bărbatul trebuie să fie cap familiei. Iubirea lui Hristos pentru Biserica Sa, jertfa Acestuia, se transpune în relațiile dintre soț şi soție. Familia constituie oglinda Bisericii, cea „una, sfântă, sobornicească şi apostolică”. ${ }^{13}$ Calea pentru un atare demers nu poate să excludă susținerea membrilor familiei pentru redescoperirea vocației de ființă religioasă, chemată să-şi asume parcursul spiritual ascendent de la chip la asemănarea cu Creatorul Său. Structurile pedagogice oferite de Sfântul Ioan Gură de Aur, mai ales, care a insistat îndeosebi asupra stabilirii unei cât mai strânse comuniuni cu îngerii şi cu sfinţii, prin alegerea numelor pentru copii din rândul acestora, respectiv pentru modelarea cu atenție a sufletelor copiilor, aflați la vârsta purităţii sufleteşti, constituie deopotrivă trepte şi şanse ale spaţiului misionar pentru familia şi Biserica de mâine $^{14}$. Liantul care descoperă lumina dragostei pentru persoană, prin care se defineşte comuniunea din familie este dragostea.

\footnotetext{
12 A se vedea şi sinteza: Teofil Tia, Rê̂ncreştinarea Europei? Teologia religiei în pastorala şi misiologia occidentală contemporană, Alba Iulia, Editura Reîntregirea, 2003.

13 Sfântul Ioan Gură de Aur, Omilia despre căsătorie, Din comentariul la Efeseni, în vol. Cateheze maritale, p. 102.

${ }^{14}$ Monica Opriş, Religie, morală, educație. Perspective teologice şi pedagogice, Bucureşti, Editura Basilica, 2011, p. 31.
} 
„Familia, care reprezintă biserica din casă, este o şcoală a iubirii, o şcoală a vieții, a creşterii duhovniceşti şi a cunoaşterii cuvântului lui Dumnezeu. Ea trebuie să devină locul propovăduirii Evangheliei împărăției lui Dumnezeu, o şcoală a întâlnirii cu Tainele şi cu slujbele Bisericii, o şcoală de pregătire pentru participarea la ele. Familia, casa constituie o şcoală atât pentru copii, cât şi pentru părinți." $" 15$

\section{Concluzii}

Familia a fost instituită de către Dumnezeu în rai prin aducerea la existență a primilor oameni, Adam şi Eva, pe care El i-a binecuvântat şi i-a aşezat să trăiască în unitate şi comuniune iubitoare (Facere 2, 24). Astfel, bărbatul şi femeia alcătuiesc „un singur trup”, împărtăşindu-se reciproc de alteritatea şi complementaritatea conjugală. Prin venirea Mântuitorului Iisus Hristos pe pământ şi, în mod special prin participarea Sa la nunta din Cana Galileii, instituția familiei a fost sfinţită şi ridicată la nivelul de Taină dumnezeiască. De aceea, pentru ca însoțirea soțului cu soția să fie sfințită şi să primească caracterul de Taină, este nevoie ca aceasta să fie făcută în biserică, cu binecuvântarea lui Dumnezeu, prin mâna preotului slujitor. Menținerea pe o traiectorie spirituală ascendentă a vieții religios-morale în familie, în contextul decentrării axiologice din actuala postmodernitate, reclamă edificarea unor modele misionare care să aibă în vedere în special familia, liantul regenerării societății, dar şi garanţia transmiterii învăţăturii revelate înspre viitoarele generații de creştini.

${ }^{15}$ Gleb Kaleda, Biserica din casă, traducere din limba rusă de Lucia Ciornea, Bucureşti, Editura Sophia, 2006, p. 55. 


\section{Bibliografie:}

1. Clement Alexandrinul, Stromatele, trad. rom. D. Fecioru, în PSB, vol. 5, Bucureşti, Editura Institutului Biblic, 1982.

2. Codrescu, Răzvan, Teologia sexelor şi Taina Nunții, Bucureşti, Editura Christiana, 2002.

3. Ecklund, E.H., Lee, K.S., Atheists and Agnostics Negotiate Religion and Family, Journal for the Scientific Study of Religion, 2011, 50(4): 728-743.

4. Eliade, Mircea, Istoria credințelor și ideilor religioase, vol. I, trad. Cezar Baltag, Bucureşti, Editura Ştiințifică, 1991.

5. Galeriu, Constantin, Jertfă şi răscumpărare, Bucureşti, Editura Harisma, 1991.

6. Hull, John M., Practical theology and religious education in a pluralist Europe, British Journal of Religious Education, 2004, 26(1): 7-19.

7. Kaleda, Gleb, Biserica din casă, traducere din limba rusă de Lucia Ciornea, Bucureşti, Editura Sophia, 2006.

8. Mihoc, Vasile , Căsătoria şi familia în lumina Sfintei Scripturi, Mitropolia Ardealului, nr. 9-10, 1985.

9. Mladin, Nicolae (coord.), Teologia Ortodoxă Morală, Alba Iulia, Editura Reîntregirea, 2003.

10. Nicholls, Emma; \& Arthur A. Stukas, Narcissism and the SelfEvaluation Maintenance Model: Effects of Social Comparison Threats on Relationship Closeness, The Journal of Social Psychology, 2011, 151(2): 201-212.

11. Opriş, Dorin, Dimensiuni creştine ale pedagogiei moderne, Bucureşti, Editura Didactică şi Pedagogică, 2012.

12. Opriş, Monica, Religie, morală, educație. Perspective teologice şi pedagogice, Bucureşti, Editura Basilica, 2011.

13. Radu, Dumitru, Postmodernismul, o provocare nihilistă la învățătura de credință şi spiritualitate ortodoxă, art. în lucrarea Simpozionul Modernism, Postmodernism şi Religie, Constanța, mai, 2005, Iaşi, Editura Vasiliana-98, 2005.

14. Sfântul Ioan Gură de Aur, Bogățiile oratorice, Oradea, Editura Pelerinul Roman, 2002.

15. Sfântul Ioan Gură de Aur, Omilia despre căsătorie, Din Comentariul la Efeseni, în volumul: Cateheze maritale. 
16. Tia, Teofil, Reîncreştinarea Europei? Teologia religiei în pastorala şi misiologia occidentală contemporană, Alba Iulia, Editura Reîntregirea, 2003.

17. Trifa, Gavril, The Holy Eucharist as Fulfillment of the Human Person, International Journal of Orthodox Theology (IJOT), 5/3., 2014, pp. 219-231,

18. Yannaras, Christos, Libertatea moralei, Bucureşti, Editura Anastasia, 2002. 